\title{
The nature of developmental and educational dysfunctions of a modern family
}

\author{
Maria Panasiuk \\ ABCDEFG
}

\author{
Vincent Pol University in Lublin, Poland
}

\begin{abstract}
The socio-psychological reality, in which the modern family functions, requires many interdisciplinary studies undertaken for diagnostic as well as corrective and therapeutic (aiding) purposes. This paper attempts to present, from the psychological perspective, the issue of dysfunction in terms of general developmental and educational problems that parents face in the upbringing process. In psychology, family is treated as the child's socio-educational primary and natural environment, in which he can gather his first life experiences. These are of diverse character and may be drawn from a variety of actions: supportive and motivating activities, passive participation in the upbringing process or negative, inhibiting interactions. A wide spectrum of variables modifying the developmental and educational process includes the child's age, level of psychic development but also broadly understood parental educational competencies shaped in objectively difficult reality and other factors modifying the family developmental and educational activities. In family educational interactions, as far as their form, content and educational methods are concerned, we should take into account current civilization-related determinants, understood as a number of social environment variables (school, peer groups, youth organizations, social movements) which influence the development of the child in a planned systematic and intended way. Susceptibility of young people to these influences gradually becomes more open and natural, often replacing the direct educational influence of the family.This paper focuses mainly on various manifestations of social life that pathologize modern developmental and educational interactions within the family, both of internal and external character.Current trends in psychoprophylaxis should also take into account interactions that would make the parents aware of numerous external threats to the modern family, indicate preventive methods, grouped in a system of actions particularly important for correct functioning of the family as well as aim at development or consolidation of parental competencies, developmental abilities, self-awareness and educational self-control. Multispecialty and multidirectional assistance to the family - the child's developmental and educational environment - in self-diagnosis of its functioning should be a priority for many specialist centers on the national scale.
\end{abstract}

Key words: family psychology, education, difficulties

Family issues and its educational duties are nowadays brought up in an unusual context. The role of the family commonly viewed as the first and natural educational environment of the child is gradually changing, also in the light of social threats as the source of negative external educational influence, which results in a spreading phenomenon of social inadequacy of children and young people.

Modern threats to educationally correct functioning of the family are not necessarily connected with pathological manifestations of its internal functioning but increasingly often with external determinants considerably limiting the possibility of direct influence on the child, connected with parental ethical and moral representation, social and personal values and rules that parents try to live by and use in the upbringing process.

In psychological literature, family environment is viewed as one of the factors of psychic development from the egzogenic group, mainly due to the possibility of influencing the child through educational and family processes that govern its development. However, when we take a much broader look at the family it becomes apparent that parental influence on children is the only environment that includes both internal (genetic-in- born) as well as external (environmental) factors and therefore it plays a special role in the child's development.

In psychology, family is treated as primary and natural educational and social environment of the child, which forms his primary life experiences. The spectrum of its influence is wide - from positive actions of supporting and activating the child's development, through passive participation in its education, to negative actions inhibiting the child's educational process. Natural and personal rights of the child to education as well as the rights and duties of parents to educate are not questioned. It is the only non-reciprocal relation from among all the educational models, but it has to be borne in mind that the family in this model may also constitute a potential source of behavioural disorders of children and their dysfunction in adaptation to rules and norms of social coexistence.

The crucial pathogenic factors present nowadays in the family environment include the following:

- Family educational failures,

- Faulty, negative parental attitudes,

- Educational models inadequate to the child's age, educational inconsistency, authoritarianism, excessive liberalism, 
- Failure at or insufficiency in satisfying the child's biological and psychological needs,

- Negative patterns of conduct and resourcefulness, negative patterns of personality maturity, inappropriate norms and values presented by parents that influence the family,

- Pathology in family life: addictions [1], physical or psychological abuse, aggression, crime,

- Absence of help in child development: lack of or inappropriate cooperation with the child, lack of respect for him, his achievements and plans,

- Neglecting the child's future, inappropriate educational and developmental care,

- Ignoring or underestimating the developmental dysfunctions of the child including partial developmental disorders, disability, handicap, chronic somatic diseases hindering proper functioning and development of the child,

- Poor financial and living conditions of the family, low socioeconomic status, unemployment.

In view of the above, a specific profile of a child from the dysfunctional family emerges, the child with unfavourable features that burden his psychological development and portend badly for his further development, i.e. the syndrome of a child from the educationally inefficient family, which manifests itself in the following:

- Excessive neurotic tendencies, emotional instability, increased tendency to experience negative emotions (fear, embarrassment, anger, guilt), high level of susceptibility to stress;

- Poor quality and frequency of social interactions, isolation, withdrawal from social relations, the feeling of hopelessness, despair, low level of activity and energy;

- Tendency to shut oneself away from new experiences, negative evaluation of life experiences, aversion to novelties, lack of cognitive curiosity;

- Adopting extreme attitudes towards others (agreeableness or antagonism), increased level of aggression (including auto-aggression);

- General lack of internal organization, persistence and motivation in actions that are goal-oriented and require planning;

- Attitude of self-rejection closely related to the feelings of grievance, guilt, inferiority, blaming and resenting oneself, lacking faith in one's abilities, underestimating one's achievements, magnifying failures, degrading oneself, as well as distortion of self-esteem;

- Psychological pessimism - tendency to see wrong in every occurrence, attitude towards the world full of fear and feeling of hopelessness.

The overall specificity of functioning of a given family, as a care (protective) and educational environment, is the subject of family diagnosis in the psychological, pedagogical and sociological dimensions.
It includes assessment of all elements of educational importance: biological, financial, social and cultural spheres [2], [3]. Psychological diagnostics dealing with the sphere of child behavior disorders, educational difficulties and dysfunctional adaptation to social life, clearly treats the family as a possible source of pathological educational and care (protective) determinants.

In family educational interactions, as far as their form, content and educational methods are concerned, we should take into account current civilizational determinants, understood as a number of social environment variables (school, peer groups, youth organizations, social movements) which influence the development of the child in a planned, systematic and intended way. Susceptibility of young people to these influences gradually becomes more open and natural, often replacing the direct educational impact of the family. The social environment factors start to penetrate the family much earlier than in the past, influencing the formation of the child's psyche, trying to replace or modify the child's natural educational environment, sometimes standing in opposition to the rules and educational methods preferred by the family.

Diverse spheres of environmental influence on young people that raise concern manifest themselves in growing degradation of direct social ties in primary educational groups (family) with the concurrent increase in importance of informal groups, to which a person is attached only with part of his personality and for a short period of time. This sphere is connected with collapse of traditional authority and simultaneous increased impact of apparent authorities, which promote culturally strange and harmful ideas and behavioral patterns [4]. Therefore, we cannot rule out the possible occurrence of "secondary care and educational failure of the family", which considerably diminishes or modifies the influence of family on the child and directs his education in accordance with modern trends.

The most important elements of the external, unfavourable for the family and the child phenomenon pertain to the following spheres:

1. Nowadays scientific trends of humanism underline special independence of a person, understood as the ability to meet one's needs and fulfill one's goals and life plans [4]. Liberalistic tendencies, preferred in the modern education, favour treatment of young people inadequately to their development, as ready for responsible participation in autonomous decision making and undertaking important life tasks. Modern youth often chooses the so-called horizontal path of their development, in which the modification of life and extend of task readiness as to their future remains at the level of manifestation actions. This phenomenon pertains to awaiting or creating facts and events that provoke and enhance emotional experiences and fascinations. They are often of terminal character - limited in time, which favours the attitude of searching for new events generating positive emotional experiences of hedonistic character (see [4]). 
2. General acceleration of the child's psychological development involves as well the construction of self-awareness. The sense of personal identity and construction of self-awareness, as traits of self-determination that enable the description of a person as different from other people [5], is a difficult process which often requires help from those with whom the person has mutually positive emotional relationship [6]. Optimally, these tasks could be performed by the family. However, sometimes the child has to walk this difficult path without his parents and not always because of their fault (excluding educational inefficiency and family pathology). It is too early that these intimate grounds of self-awareness are entered by external factors which markedly affect the way the child forms his perception of himself and the world. This influence may be positive, but often the child draws negative patterns, social and personal ideals and norms of self-conduct and the vision that he creates of himself and the surrounding world is not always consistent with standards and values preferred by the family.

3. Nowadays the construction of personal identity by the youth takes place earlier, almost simultaneously with the formation of social identity. This makes it difficult to obtain reliable information, thoroughly assess facts and make the right choices concerning the child and his life goals. The child builds the image of himself, his aspirations and goals hastily and superficially, often abandoned by the family and pressed by the requirements of the outside world.

Modern models of family underestimate the value of constructing the child's identity based on ideas and values recognized by parents and often neglect the formation of system of values preferred by the family. The void that appears is easily filled with influence of external, extra-family environments.

Hence, the social identity develops parallelly to the personal one. These two processes do not always complement each other and their assimilation and mutual valuation provokes in young people unfavourable internal experiences of cognitive and emotional character. The striving for, often at all cost, group acceptation, feeling significant and building self-esteem in the extra-family environment generates contradictions and internal conflicts, especially if psychological needs of the child (acceptation, love, the sense of belonging and recognition) are not fully met at home. Searching to satisfy these needs outside the family environment does not always lead to group structures that are valuable and consistent with the family educational model.

4. Adolescents are particularly susceptible to various psychological fluctuations, sudden or gradual, when taking decisions concerning their future provokes numerous contradictions and internal rebellions. This does not always favour integration and success in realization of one's goals. The multitude of new life roles adopted during adolescence often breeds chaos in a young person's psyche which influences the formation of neg- ative identity [7], often leading towards social maladjustment, crime or addictions. During this time youngsters become considerably more open and susceptible to influence of modern social and youth groups, which propagate various ways of living a "happy life". Lack of sufficient explanation of these ideas or their multitude, provoke disorientation and are overwhelming for the adolescent. Success, freedom, happiness and money are slowly becoming a mantra for the young generation. These are backed up by slogans taken from the western culture: "I deserve it, I have the right, I earned it". Populist movements and youth organizations do not take into account cultural distinctiveness of adolescents, which plays a crucial role in understanding many notions governing the development of an individual and social order in the place where he was born, brought up and socially active. This way the process of formation of ethnical and cultural identity becomes disturbed [8].

Accelerated tempo of social changes affects all aspects of human development. Generally, available multitude and diversity of proposals as to basic values of a modern man, ethical and moral norms, life goals and standards of conduct generate the sense of chaos and danger, resulting in increased pugnacity and aggression. The dilemmas, conflicts and uncertainties concerning personal choices affect the functioning of a child in the family, negatively influencing his relations with parents. These harmful phenomena increase generally observed intra-family difficulties in communication.

5. A new disturbing phenomenon spreading among youngsters is permanent and persistent comparing oneself, one's values, goals and achievements to peers, to imaginary western models, media-promoted "European standards", including in all aspects of existence and one's family actions. It often generates the sense of social, moral and family provincialism amplified by the media, resulting in unfavourable psychic experiences such as stress, frustration, low self-esteem and underestimation of one's achievements. Such a psychosocial aura has negative impact on our strives and ambitions, influences adversely the sense of order and logical consequence of events and experiences from our family life. The pathology of educational mechanisms influencing the child from the moment of his birth is even more acute, since these unfavourable influences are first to appear and form the psychological development of the child at least until the moment he becomes independent. In accordance with the widely recognized rule that the sooner the adverse factor begins to act the more serious and profound damage it causes, educational malfunctions generate irreversible negative consequences, neglect in development, and in consequence bad habits concerning behavior and actions. Making the family realize that is extremely difficult. In educating their children, many parents try to function within the limits of the so-called social norms. The external negative specialist assessment is viewed by the family as unauthorized interference with its internal problems, and 
the reception and evaluation of threats to the educational process are carried out from the wrong perspective.

6. Modern youth is marked by excessive desire to achieve success, be noticed and admired, gain personal recognition, distinguish oneself and be appreciated by others, which unfortunately favours not easily noticeable alienation of the youngster from his family environment. This phenomenon is exacerbated by increasing difficulties in proper communication with parents and other family members. Inability to initiate and maintain contacts with members of the family results not only from the lack of time but also from the fundamental ignorance concerning expression of one's thoughts and emotions in a clear and mutually acceptable manner. Therefore, it is common that not enough attention is paid to ways of enhancing communication, such as direct closeness of interlocutors, willingness to listen to the other person, openness and correct understanding of the conveyed messages, cooperation, emotional, clear, concrete and precise expression of thoughts, partnership approach, control over one's feelings and paying attention.

7. Today's social reality disturbs the family educational and prophylactic influence on children. External social determinants which enter the life of young people very early are difficult to control and adjust to the norms and values accepted by the family. Therefore, we can no longer talk only of intra-family pathogenic factors and see the family as the first potential source of disorders in social adjustment of children and adolescents. Modern threats to educational influence of family appear regardless of its educational efficiency, financial status and living conditions, lack or presence of advanced pathology. These threats are of external nature, that structure and modify the accepted patterns of pro-social behavior as well as moral and normative beliefs of parents. This adverse influence is often a prerequisite to adverse and pathologic prognoses - psychological, pedagogical and sociological.

8. The family has been long abandoned in its educational efforts, partly because of deteriorating financial and living conditions and partly due to numerous directives issued by superior authorities as to the scope of its influence on the child. Estimation of what is wrong and what is right is often imposed and takes place without the knowledge and approval of parents. System preferences concerning educational liberalism limit the possibility or even make it impossible to use the instruments of penalty and award. The system of penalizing parents for improper care over children also requires improvements which leads to the phenomenon commonly known as "secondary family malfunctioning". Nowadays the family often faces an artificially created dilemma: whether to be "modern", that is do not teach, do not demand, do not see, or do the opposite - be an old-fashion style family and demand, make problems, give the child educational tasks adjusted to his possibilities for him to solve independently.
Social prophylaxis, although directed at the child's personality is at the same time a set of complex and longitudinal actions that happen in the environment [4], see [9]. Therefore, the effectiveness of prophylaxis depends not only on actions taking into consideration personality traits of children, but also on the understanding of specificity of developmental environments: educational and social, the influence of which determines the conditions of the child's social development.

Current trends in prophylaxis should take into account actions which would make parents realize numerous external threats to the modern family and would offer ways to fight them. Psychological prevention, understood as a complex of methods and psychological means used in order to prevent adverse phenomena in family life resulting in disorders in its educational functioning may be of primary, secondary (see [8]) or corrective-compensative character.

Preventive actions of primary character, as far as the family pathogenesis is concerned, should be aimed at decreasing the risk of disorders in family functioning, in parents - child relations, through anticipating and counteracting adverse factors. Secondary actions are used when early signs of disorders are detected to stop their escalation and limit their duration. Corrective and compensatory prevention should be construed as avoiding the effects of negative experiences, counteracting possible recurrences, minimizing secondary disorders resulting from primary pathological factors.

Specialist preventive management should also be introduced to parent self-diagnosis in the case of difficulties in the educational process or disorders in child's functioning, both sudden and increasing gradually, since this diagnosis is often based on negative patterns of knowledge of oneself. It pertains to the negative self-image of the parent, where psychological defensive mechanisms set the scope and subjective assessment of the emotionally difficult situation. The profile of this negative assessment of oneself may be based on the intensity of features forming the so-called "syndrome of a parent faced with educational threats", which manifests itself in the following ways:

- Emotional symptoms: depressed mood, sadness and anxiety, inability to enjoy life, sensitivity;

- Cognitive symptoms: negative image of oneself as an indolent parent, low self-esteem, self-accusation, pessimism and resignation;

- Motivational symptoms: problems with mobilisation for action, general psychomotor slowdown apathy, problems in taking decisions;

- Somatic symptoms: sleep and wakefulness disorders, loss of or excessive appetite, weakness and fatigue, general malaise, hypersensitivity to pain.

The main preventive strategy should include reinforcement of parents' personal competencies by providing them with knowledge and practical skills to cope 
with educational difficulties, including the following concepts:

1. Self-knowledge - self-assessment- self-acceptance, self-esteem, proper self-image

2. Self-control - ongoing control of emotions, judgments and manners of reaction to difficult situations, drawing conclusions and more effective forward-looking actions

3. Self-realization - self-actualization, striving to realize one's personal potential, developing talents and skills, internal coherence. A self-realizing person should be spontaneous in thinking and action, have distance towards oneself and occurring events, maintain close relationships with other people and be independent.

4. Self-development - attention to personal development, internal work which may bring change in behaviour, habits and attitudes. The process requires time, motivation, ambition, persistence and devotion. The desire to change, form new values and improve the old ones should be strong enough to resist fear of being ridiculed or objections from family members and friends.

Discussing pathogenic family factors that cause disorders of socialization processes, we should also mention the disturbing secondary symptoms of crypto-pathologization of family environment developing gradually and effectively through the following negative influences:

- Media, gradual limiting of the authority of family and its educational actions in the name of falsely understood child's right of self-determination;

- Deprivation or limitation of basic instruments of educational impact (punishment) in favour of independent actions of the child, excessive to his age, often lacking the values and rules commonly accepted in the society, which are passed over by the family environment;

- Alcoholism and other forms of addiction, such as substance abuse, drug dependence, cell phones, the Internet, that are spreading among young people, provoke disturbing ways of dealing with difficult situations manifesting in considerably increased levels of stress, frustration and aggressive behavior;

- Early and adverse to the child's development and strength of parent-child relationship use of foster care (nursery, kindergarten, school common room) with simultaneous negligence of the direct educational influence of the family;

- Difficulties in understanding each other and maintaining proper communication with the child, often related to poor skills of parents;

- Depriving parents of influence on the profile of their own educational actions through rules and conditions set by superior authorities concerning "correct educational situations";

- Making the parents give up their educational roles and responsibility for care and education of children executed through the system;

- Considerable and dangerous relaxation of interpersonal bonds in the family that points to numerous neglected and underestimated areas of care and educational reality, including the role played by grandparents, siblings, distant relatives and other people important for the child;

- Low level of psychic-emotional support and sense of security in the family observed currently, which provokes loneliness and lack of understanding among children and adolescents, increasing as well the orphanhood and social maladjustment rates.

Methods of personal influence of parents seem nowadays very limited, decreasing in strength and scope as the child grows. The basic psychological factor that can cement the intrafamily relationships is the bond with the child - directing his actions through advice, minimizing various factors that provoke development of adverse, antisocial attitudes and organizing certain elements of the educational environment through skillful directing of interests, abilities and talents of the child to motivate him to provoke positive personal attitudes towards current social norms.

Another neglected type of family educational actions concerns the ways to cope with psychological effects of adverse and pathological factors (see [10]) present in the external social environment.

Current prophylactic actions, particularly important for correct functioning of the family and coping with challenges and difficulties of the present reality, should be focused on development and strengthening of the family hard and soft competencies, i.e. broadly understood assistance activities aimed at propagation of correct models of functioning of the family - the basic development and educational environment for the child.

Usefulness of competencies defined in psychological literature seems here of extreme importance and preparation of methodological basis of education of parents may increase their level of self-awareness and educational self-control:

- making the family aware of, and, if necessary, working out family models and effective methods of communication, including rules of assertive educational influence,

- detailed, constantly monitored analysis of methods and effects of the means of communication used by the family,

- working out patterns of mutual understanding, compassion, sympathy, acceptance and tolerance with simultaneous objection to the child's behaviour contradicting the rules and norms of family coexistence,

- understanding of the essence of parenthood and responsibility for the development of the child as well as respect of the child's rights in all developmental domains, in line with the requirements of his age, 
- respect of special developmental potential of a handicapped child or a child requiring individualized efforts and treatment in the educational process,

- improving psycho-pedagogical knowledge of stages and particular requirements of the child's development, his psycho-physical needs, ways to satisfy them in a manner adjusted to the stage of their development and their maturity,

- acquiring knowledge concerning the essence of parental attitudes, family educational models, as well as unification of attitudes and values preferred by parents, aiming at education of the child,

- formation and self-control of proper parental attitudes based on self-experience, acquired knowledge and drawing thorough conclusions as well as on compromises in cooperation of marital-parental systems in this respect,

- control over parental ambitions, flexible adjustment of parental visions of the child's future to the child's individual abilities as far as his general development, intellect and emotions are concerned,

- development of substantive and practical methods of coping with stress, difficulties and failures as well as aggressive and pathological behaviour.

Generally, the understanding of prophylaxis concerning educational influence on children and adolescents raises serious concerns; hence, the practical approach to this issue is viewed as inadequate, non-systemic and ineffective. Institutionalized actions in this respect are of fragmentary character and are undertaken sporadically, which suggest absence of complex concepts and plans from the competent institutions.

Multispecialty and multidirectional assistance to family - the child's developmental and educational environment - in self-diagnosis of its functioning, should be a priority for many specialist centers on the national scale.

\section{References:}

1. Gąsior K.; Funkcjonowanie noo - psychospołeczne i problemy psychiczne dorosłych dzieci alkoholików. Wydawnictwo Difin, Warszawa 2012.

2. Wysocka E.; Diagnoza w resocjalizacji. Wydawnictwo Naukowe PWN. Warszawa 2008.

3. Farnicka M.; Między wyborem, a przymusem. Rodzina a sposób radzenia sobie w różnych sytuacjach. Wydawnictwo Difin, Warszawa 2013.

4. Rybczyńska D. (Red.); Ciągłość i zmiana w obszarze profilaktyki społecznej i resocjalizacji. Oficyna Wydawnicza „Impuls”. Kraków 2003.

5. Reber Arthur. S., Reber Emily. S.; Słownik Psychologii. Wydawnictwo Naukowe Scholar. Warszawa 2005.

6. Boulvin Y.; Klucz do zrozumienia relacji rodzice dzieci. Wydawnictwo: W Drodze, Poznań 2014.

7. Harwas - Napierała B., Trempała J.; Psychologia rozwojowa człowieka. T.2. Wydawnictwo Naukowe PWN. Warszawa 2000.

8. Sęk H.; Społeczna psychologia kliniczna. Wydawnictwo Naukowe PWN. Warszawa 1998.

9. Szczęsny W.W. Zarys resocjalizacji z elementami patologii społecznej i profilaktyki. Wydawnictwo Akademickie „Żak”, Warszawa 2003.

10. Urban B., Stanik J.M. (red.); Resocjalizacja. Teoria i praktyka pedagogiczna. T.1. Wydawnictwo Naukowe PWN. Warszawa 2008.

\section{Correspondence address:}

dr Maria Panasiuk prof. WSSP

Wyższa Szkoła Społeczno - Przyrodnicza

w Lublinie, ul. Choiny 2

maria.panasiuk@onet.eu 